\title{
Green tea catechins augment the antitumor activity of doxorubicin in an in vivo mouse model for chemoresistant liver cancer
}

\author{
GANG LIANG ${ }^{1}$, ANZHOU TANG ${ }^{2}$, XIAOZHEN LIN $^{1}$, LI LI $^{1}$, SU ZHANG $^{1}$, \\ ZHIMING HUANG ${ }^{1}$, HAIHUA TANG ${ }^{1}$ and QINGDI QUENTIN LI $^{3}$ \\ ${ }^{1}$ Department of Pharmacology, School of Preclinical Sciences and ${ }^{2}$ First University Hospital, \\ Guangxi Medical University, Nanning 530021, P.R. China; ${ }^{3}$ National Institute of Allergy \\ and Infectious Diseases, National Institutes of Health, Bethesda, MD 20892, USA
}

Received January 19, 2010; Accepted March 9, 2010

DOI: 10.3892/ijo_00000659

\begin{abstract}
Green tea catechins have been reported to have antitumor activity. The objective of this study was to examine the effect of catechins on the antitumor efficacy of doxorubicin (DOX) in a murine model for chemoresistant hepatocellular carcinoma (HCC). Epicatechin gallate (ECG) and epigallocatechin gallate (EGCG) are the most abundant polyphenolic compounds in green tea. Here, we show that ECG or EGCG at higher doses had a slight inhibitory effect on cell proliferation in the resistant human HCC cell line BEL-7404/DOX in vitro and in vivo, whereas the administration of DOX with these compounds at lower doses significantly inhibited HCC cell proliferation in vitro and hepatoma growth in a xenograft mouse model, compared with treatment with either agent alone at the same dose. Furthermore, the administration of DOX in combination with ECG or EGCG markedly enhanced intracellular DOX accumulation, which implies that the catechins inhibited P-glycoprotein (P-gp) efflux pump activity. Consistent with these results, the intracellular retention of rhodamine 123, a P-gp substrate, was increased and the level of P-gp was decreased in cells concurrently treated with DOX and ECG or EGCG. EGCG increased topo II expression, but did not alter GST protein levels in tumor xenografts. The expression of MDR1 and HIF-1 $\alpha$ mRNA was obviously reduced, whereas MRP1 and LRP expression was not changed significantly. These data suggest that tea catechins at non-toxic doses can augment DOX-induced cell killing and sensitize chemoresistant HCC cells to DOX. The chemosensitizing effect of catechins may occur directly or indirectly by reversal of multidrug resistance, involving the suppression of MDR1
\end{abstract}

Correspondence to: Dr Qingdi Quentin Li, National Institute of Allergy and Infectious Diseases, National Institutes of Health, Building 10, Room 11N234, Bethesda, MD 20892, USA

E-mail: liquenti@niaid.nih.gov

Key words: green tea, catechins, hepatocellular carcinoma, multidrug resistance, doxorubicin, mouse model, in vivo study expression, or by enhancement of intracellular DOX accumulation, involving inhibition of $\mathrm{P}$-gp function.

\section{Introduction}

Primary liver cancer represents a major health burden and the main cause of cancer-related mortality in the world $(1,2)$, although its incidence varies geographically. Of the two major types of primary liver cancer, hepatocellular carcinoma (HCC) and cholangiocarcinoma, HCC occurs more frequently in China. More than 500,000 new patients are diagnosed each year, with an incidence in men twice that of women. In addition, the rate of new liver cancer cases has been rising over the past 10 years in the United States. In 2006, it was estimated that 18,500 Americans would be newly diagnosed with liver cancer, and 16,200 would die of the disease.

$\mathrm{HCC}$ is a very aggressive cancer with a dismal outcome; patients usually survive less than one year after diagnosis. The possibility of curative treatment depends on both tumor stage and liver function (3). Although a wide range of therapeutic options is available, the efficacy of these methods and the survival of patients with HCC remain poor. Surgical resection is currently the most effective treatment for early-stage HCC patients with preserved liver function and without distant metastasis. Doxorubicin (DOX)-based adjuvant chemotherapy is used primarily in advanced HCC cases with liver dysfunction and an unresectable tumor, or following curative resection. Although the short-term prognosis of HCC patients has improved recently due to advances in early diagnosis and treatment, the long-term prognosis is still far from satisfactory, mainly because of HCC recurrence and the development of resistance to chemotherapy.

Upon exposure to one chemotherapeutic agent in the clinic or laboratory, hepatoma cells can acquire resistance to a wide variety of diverse and unrelated drugs with different structures, different functions, and different intracellular sites of action. This phenomenon, called multidrug resistance (MDR), accounts substantially for the clinical failure of tumor chemotherapy, and considerable efforts have been made toward understanding MDR (4). Some studies have focused on the identification of biological and pharmacological agents with 
low toxicity and few side effects that may reverse MDR in patients with HCC. Recently identified MDR reversal agents or chemosensitizers such as verapamil (VPL), cyclosporin A, and tamoxifen have limited clinical applications because of their undesirable pharmacological toxicity and side effects (5). There is a need for compounds with fewer side effects that can effectively treat HCC or reverse MDR during chemotherapy of this disease. One candidate agent for this role is tea catechin.

Tea (Camellia sinensis) is one of the most popular prepared drinks in the world and is available as black tea, green tea, Oolong tea, and white tea (6). Approximately $20 \%$ of dried tea manufactured worldwide is green tea, which is prepared in such a way as to preclude the oxidation of green leaf polyphenols. The major components of green tea are polyphenols, and the major polyphenols in green tea are flavonoids. Epicatechin gallate (ECG) and epigallocatechin gallate (EGCG) (Fig. 1) are the most abundant polyphenolic compounds in green tea, and EGCG is viewed as the most significant active component (6).

One of tea's prime benefits is thought to be its contribution to lowering the risk for stroke, as it helps to maintain vascular tone (elasticity) and reduce oxidization of fat circulating in the blood. Studies have documented that green tea catechins, a group of polyphenolic compounds, are responsible for the anti-inflammatory and anti-oxidant potential of green tea (6). Green tea has been used to treat cardiovascular diseases, oral cavity diseases, and Parkinson's disease, and has a wide range of uses related to diabetes, exercise enhancement, inflammatory bowel disease, and skin disorders (6). Well-controlled epidemiologic studies have suggested that green tea can alter the brain aging process by serving as a neuro-protective agent (6). Recent studies have also reported that tea phytonutrients may help protect against some cancers. For example, tea polyphenols have been shown to have activity against cancer of the prostate, stomach, intestine, and colon (6). Animal studies have demonstrated that green tea can help protect against the development of liver tumors in mice. Kuo and Lin have shown that EGCG inhibits proliferation in cells of the human liver cancer cell line Hep G2 by inducing apoptosis and blocking cell cycle progression in G1 phase (7). However, the effect of catechins on the reversal of MDR in resistant human HCC in vivo is unknown.

This study was designed to define the biological and therapeutic effects of catechins in the treatment of HCC. We focused on ECG and EGCG, which are recognized as the most abundant and most active polyphenols in green tea. We assessed whether these compounds could mediate cell growth inhibition in an in vivo murine model for DOX-resistant human HCC. We also examined whether the green tea polyphenols were able to increase the intracellular accumulation of DOX in our system. Finally, we tested the ability of EGCG to inhibit the in vivo protein expression of $\mathrm{P}$-glycoprotein (P-gp) and mRNA expression of several drug resistance genes, which have been shown to be associated with drug resistance in many human tumors.

\section{Materials and methods}

Chemicals and reagents. Doxorubicin hydrochloride was purchased from Pharmacia \& Upjohn Co., Italy. Epigallo- catechin and epigallocatechin-3-gallate from green tea were obtained from Dr Lei Yaoxing (Guangxi Medical University, Nanning, Guangxi, China). Verapamil hydrochloride was obtained from Shanghai Hefeng Pharmaceutical Co., Ltd. (Shanghai, China). Dimethylsulfoxide (DMSO) was purchased from Guangzhou Xingang Co., Ltd. (Guangzhou, Guangdong, China), RPMI-1640 medium was from Gibco-BRL Life Technologies, Inc. (Gaithersburg, MD, USA), and fetal bovine serum (FBS) was from Hangzhou Sijiqing Co., Ltd. (Hangzhou, Zhejiang, China). The TRIzol kit and polymerase chain reaction (PCR) amplification primers were obtained from Shanghai Sangon Biological Engineering Technology and Service Co., Ltd. (Shanghai, China). Takara Taq polymerase was purchased from Takara Biotechnology Co., Ltd. (Dalian, Liaoning, China). The first-strand cDNA synthesis kit, DNA polymerase, DNA markers (DL2000), RNase, and MassRuler ${ }^{\mathrm{TM}}$ DNA ladder were from MBI, Inc. (Salt Lake City, UT, USA). Agarose was from Promega (Madison, WI, USA), propidium iodide (PI) and diethylpyrocarbonate (DEPC) were from Sigma-Aldrich Co. (Hong Kong, China), and 3(4,5-dimethylthiazol-2-yl)-2,5-diphenyl tetrazolium bromide (MTT) was from Amresco, Inc. (Solon, OH, USA).

Cell lines and cell culture. The HCC cell lines BEL-7404 and BEL-7404/DOX were obtained from the Department of Immunology, Cancer Hospital of Guangxi Medical University (Nanning, Guangxi, China). The doxorubicin (DOX)-resistant cell line BEL-7404/DOX had been developed from the parental human HCC BEL-7404 cell line by prolonging cell exposure to DOX at gradually increasing doses.

BEL-7404 and BEL-7404/DOX cells were maintained at subconfluence in RPMI-1640 medium supplemented with $10 \%$ FBS, $100 \mathrm{U} / \mathrm{ml}$ penicillin G (Shandong Lukang Pharmaceutical Co., Ltd., Jining, Shandong, China), and $100 \mu \mathrm{g} / \mathrm{ml}$ streptomycin (Dalian Merro Pharmaceutical Co., Ltd., Dalian, Liaoning, China), in an incubator (Forma Scientific, Inc., Marietta, $\mathrm{OH}, \mathrm{USA}$ ) at $37^{\circ} \mathrm{C}$ in a humidified atmosphere of $5 \%$ $\mathrm{CO}_{2}$. DOX $(0.1 \mu \mathrm{g} / \mathrm{ml})$ was added to the culture medium for BEL-7404/DOX cells, to maintain DOX-resistance. For subculturing, cells were dissociated using $0.25 \%$ trypsin (Amresco, Inc.) with $0.02 \%$ EDTA (Guangdong Xilong Chemical Co., Ltd., Guangzhou, Guangdong, China).

Cell proliferation and survival assay. To determine the effect of catechins on DOX-inhibited growth and proliferation of human liver cancer cells, cell viability was assessed by MTT assay, using a commercial cell proliferation assay kit (Promega) according to the manufacturer's instructions. In brief, $100 \mu 1$ of medium containing $5 \times 10^{3}$ BEL-7404 or BEL-7404/DOX cells were distributed evenly in each well of 96-well plates, and the cells were grown for $24 \mathrm{~h}$. The cells were then treated in quadruplicate with ECG, EGCG, VPL, and DOX, respectively, at the concentrations indicated in each experiment and incubated for 48-72 h. At the designated incubation time, $20 \mu \mathrm{l}$ of MTT $(5 \mathrm{mg} / \mathrm{ml})$ were added to each well, and the plates were incubated at $37^{\circ} \mathrm{C}$ in a $5 \% \mathrm{CO}_{2}$ atmosphere for $4 \mathrm{~h}$. Then, the culture medium was removed, and DMSO (150 $\mu \mathrm{l})$ was added for 10 min with shaking. The optical density at $490 \mathrm{~nm}$ was determined using a Bio-Rad Model 450 microplate reader (Bio-Rad, Hercules, CA, USA). The control wells were set as zero absorbance. The percentage 


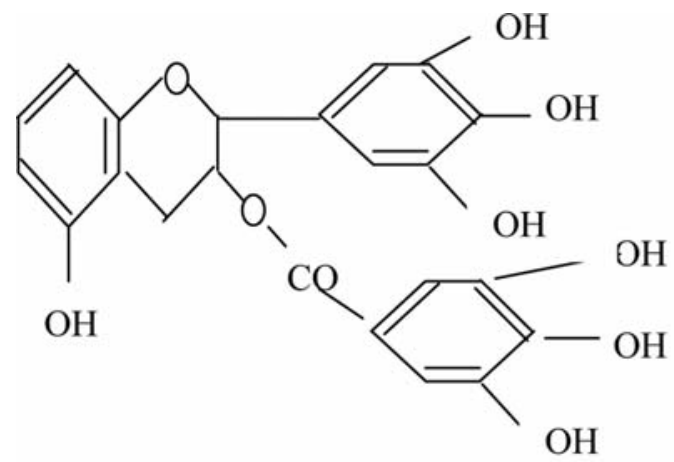

(A) Epigallocatechin gallate (EGCG)

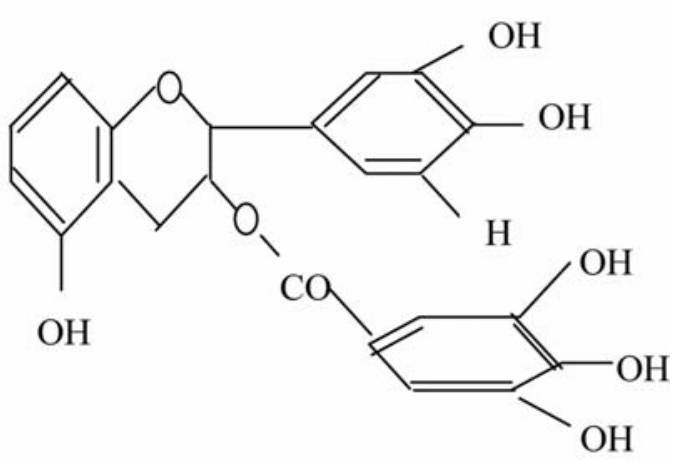

(B) Epicatechin gallate (ECG)

Figure 1. Chemical structure of two monomers of catechin.

of cell survival was calculated using the background-corrected absorbance, as follows: \% Cell viability $=\left(\mathrm{OD}_{\text {experimental }} /\right.$ $\left.\mathrm{OD}_{\text {control }}\right) \times 100$.

All experiments were performed at least 3 times, and representative data are presented. The $\mathrm{IC}_{50}$ values are the drug concentrations causing a $50 \%$ reduction in optical density. The fold drug resistance was calculated as the $\mathrm{IC}_{50}$ of BEL7404/DOX divided by the $\mathrm{IC}_{50}$ of BEL-7404. The degree of reversal of drug resistance (reversal fold or RF) was calculated as the $\mathrm{IC}_{50}$ before catechins divided by the $\mathrm{IC}_{50}$ with catechins. The relative reversal rate $(\mathrm{RRR})$ was calculated as: $(\%)=\left[\left(\mathrm{IC}_{50}\right.\right.$ of DOX alone in MDR cells - $\mathrm{IC}_{50}$ of DOX with catechin in MDR cells $) /\left(\mathrm{IC}_{50}\right.$ of $\mathrm{DOX}$ alone in MDR cells - $\mathrm{IC}_{50}$ of DOX alone in parental cells)] x 100.

Experimental animals and breeding. Equal numbers of male and female BALB/c nu/nu mice with an experimental animal quality certificate (SCXK 2003-0003; Shanghai, China) were purchased from Silaike Experimental Animal Co., Ltd., Shanghai Experimental Animal Center, Chinese Academy of Medical Sciences (Shanghai, China). The mice, 4-5 weeks of age and 13-17 g each, were raised at the Experimental Animal Center of Guangxi Medical University under specific pathogenfree conditions with a 12-h light/12-h dark cycle and constant temperature of $24^{\circ} \mathrm{C}$. All animal experiments were performed according to the institutional guidelines.

In vivo mouse model studies for HCC growth inhibition. Experimental nude mice (BALB/c nu/nu) were transplanted subcutaneously on the right axilla with $0.2 \mathrm{ml}$ of cell suspension containing $5 \times 10^{7}$ BEL-7404/DOX HCC cells. After the tumors were established, the mice were divided into six groups ( $n=10 /$ group, 5 males and 5 females) and injected with PBS only (control), DOX alone ( $2 \mathrm{mg} / \mathrm{kg}$, q4d, ip; DOX), EGCG alone (80 mg/kg, qd, ig; EGCG), DOX combined with low-dose EGCG (40 mg/kg, qd, ig; DE low group), DOX combined with medium-dose EGCG $(80 \mathrm{mg} / \mathrm{kg}$, qd, ig; DE mid group), and DOX combined with high-dose EGCG (160 mg/kg, qd, ig; DE high group), respectively. Tumor dimensions were measured with calipers every 2 days. The mean tumor volume was calculated as width ${ }^{2} \mathrm{x}$ length $\mathrm{x} 0.52$. All measurements were performed in a coded, blinded fashion. The mice were sacrificed at day 33 after drug administration, tumor growth and body weight were determined as previously described by Jin et al (8), and the tumors were resected to measure the intracellular accumulation of DOX by fluorospectrophotometry, to assess the P-gp level by immunohistochemistry, and to detect MDR1 mRNA expression by semi-quantitative RT-PCR analysis.

Semi-quantitative RT-PCR analysis of mRNA expression of drug resistance-associated genes. Total cellular RNA was isolated from $1 \times 10^{6}$ cells using a TRIzol one-step extraction assay (Shanghai Sangon Biological Engineering Technology and Service Co., Ltd.) according to the manufacturer's instructions. Total RNA $(1 \mu \mathrm{g})$ was reverse transcribed to cDNA using a GeneAmp RNA PCR kit (MBI, Inc.), and primers were chemically synthesized with a DNA synthesizer. The primers used for $M D R 1, L R P, M R P 1, H I F-1 \alpha, \beta$-actin, and $\beta 2-M G$ gene amplification are shown in Table I. Each PCR mixture (total volume, $50 \mu \mathrm{l}$ ) contained $1 \mathrm{X}$ PCR buffer, $2 \mathrm{mM} \mathrm{MgCl}_{2}, 800 \mu \mathrm{M}$ each dNTP, $1 \mu \mathrm{M}$ each primer, $50 \mathrm{ng}$ of cDNA, and 2 units of Taq polymerase. The reaction was performed in a Peltier thermocycler (PTC-220, MJ Research, Inc., Watertown, MA, USA) for 30 cycles of $94^{\circ} \mathrm{C}$ for $30 \mathrm{sec}$, $54-57^{\circ} \mathrm{C}$ for $40 \mathrm{sec}$, and $72^{\circ} \mathrm{C}$ for $50 \mathrm{sec}$. The amplified products (Table I) were separated by electrophoresis in $2.5 \%$ agarose gels in TBE at $150 \mathrm{~V}$ for $1 \mathrm{~h}$ and stained with ethidium bromide. The image was captured with a Bio-Rad Gel Doc 2000 gel imaging analyzer (Bio-Rad Laboratories, Steenvoorde, France). The relative mRNA level of each gene was calculated by normalization to the $\beta$-actin or $\beta 2-\mathrm{MG}$ mRNA level, using Quantity One analytic software (Bio-Rad).

Detection of intracellular DOX accumulation in cultured HCC cells and cells of xenograft tumors from living mice. Cultured BEL-7404/DOX cells in logarithmic phase were dissociated, $100 \mu 1$ of $7 \times 10^{6}$ cells $/ \mathrm{ml}$ were added in triplicate to each well of 96-well microplates, and the cells were grown to $70-80 \%$ confluence. The plates were divided into eight groups, and the cells were treated with DOX at 1.2, 2.5, 3.6, or 
Table I. RT-PCR primer sequences, melting temperatures $\left(\mathrm{T}_{\mathrm{m}}\right)$, and amplification products for several drug resistance-related genes.

\begin{tabular}{|c|c|c|c|c|}
\hline Gene & Direction & Sequence $\left(5^{\prime}-3^{\prime}\right)$ & $\mathrm{T}_{\mathrm{m}}\left({ }^{\circ} \mathrm{C}\right)$ & PCR product (bp) \\
\hline$m d r 1$ & $\begin{array}{l}\text { Sense } \\
\text { Antisense }\end{array}$ & $\begin{array}{l}\text { CCCATCATTGCAATAGCAGG } \\
\text { GTTCAAACTTCTGCTCCTGA }\end{array}$ & 54 & 157 \\
\hline mrpl & $\begin{array}{l}\text { Sense } \\
\text { Antisense }\end{array}$ & $\begin{array}{l}\text { TGAAGGACTTCGTGTCAGCC } \\
\text { GTCCATGATGGTGTTGAGCC }\end{array}$ & 54 & 256 \\
\hline $\operatorname{lrp}$ & $\begin{array}{l}\text { Sense } \\
\text { Antisense }\end{array}$ & $\begin{array}{l}\text { TTCTGGATTTGGTGGACGC } \\
\text { ACTTCTCTCCCTTGACCAC }\end{array}$ & 57 & 285 \\
\hline hif-1a & $\begin{array}{l}\text { Sense } \\
\text { Antisense }\end{array}$ & $\begin{array}{l}\text { TCAAAGTCGGACAGCCTCA } \\
\text { CCCTGCAGTAGGTTTCTGCT }\end{array}$ & 54 & 459 \\
\hline$\beta$-actin & $\begin{array}{c}\text { Sense } \\
\text { Antisense }\end{array}$ & $\begin{array}{l}\text { AAGCAGGAGTATGACGAGGATCCG } \\
\text { GCCTTCATACATCTCAAGTTGG }\end{array}$ & 55 & 559 \\
\hline$\beta 2-m g$ & $\begin{array}{c}\text { Sense } \\
\text { Antisense }\end{array}$ & $\begin{array}{l}\text { ACCCCCACTGAAAAAGATGA } \\
\text { ATCTTCAAACCTCCATGATG }\end{array}$ & 57 & 189 \\
\hline
\end{tabular}

$4.8 \mu \mathrm{g} / \mathrm{ml}$ either alone or in combination with ECG $(60 \mu \mathrm{g} / \mathrm{ml})$ or EGCG $(14 \mu \mathrm{g} / \mathrm{ml})$. The cells were then incubated at $37^{\circ} \mathrm{C}$ for an additional $4 \mathrm{~h}$. To measure intracellular DOX accumulation in xenograft tumor cells, the tumors were resected from the mice sacrificed in the animal model studies described above, and the HCC cells were collected. A total of $1 \times 10^{8}$ cells per sample were washed 3 times with cold PBS, resuspended in $0.3 \mathrm{~N} \mathrm{HCl}$ in $50 \%$ ethanol, and disrupted by sonication for $30 \mathrm{sec}$. After centrifugation at 10,000 rpm for $15 \mathrm{~min}$, the DOX concentration in the supernatant was measured by fluorospectrophotometry (RF-5301PC, Shimadzu Ltd., Japan) with excitation and emission wavelengths of 500 and $590 \mathrm{~nm}$, respectively. The DOX concentration $\left(\mu \mathrm{g} / 10^{8}\right.$ cells) was calculated from a standard curve prepared using known amounts of DOX.

Rhodamine 123 (rho123) retention assay. Studies were carried out in BEL-7404 and BEL-7404/DOX cells as described by Xu et al (9). Briefly, BEL7404 or BEL7404/DOX cells were treated with DOX alone $(2 \mu \mathrm{g} / \mathrm{ml})$, DOX in combination with ECG $(60 \mu \mathrm{g} / \mathrm{ml})$, or DOX in combination with EGCG $(14 \mu \mathrm{g} / \mathrm{ml})$ for $4 \mathrm{~h}$, after which the cells were collected and incubated with rho123 (Sigma-Aldrich Co., Hong Kong, China) at a final concentration of $5 \mu \mathrm{g} / \mathrm{ml}$ at $37^{\circ} \mathrm{C}$ and $5 \% \mathrm{CO}_{2}$ for $30 \mathrm{~min}$. After incubation, the cells were washed 3 times with phosphate-buffered saline (PBS) at $4^{\circ} \mathrm{C}$, and the mean fluorescence intensity of intracellular rho123 was detected using flow cytometry (FACSCalibur; Becton-Dickinson, Beijing, China) with excitation and emission wavelengths of 488 and $530 \mathrm{~nm}$, respectively. All analyses were performed in triplicate in three independent experiments. The results are expressed as the mean fluorescence intensity, which reflects the cellular content of the retained dye.

Quantitative analysis of P-glycoprotein in cultured HCC cells. The amount of P-gp was analyzed quantitatively by fluorescence-activated cell sorting. After BEL-7404/DOX cells were treated with rho123 as described above for the retention assay, they were washed once with PBS ( $\mathrm{pH} 7.4$ ) and combined with anti-P-gp monoclonal antibody MRK16 (Dako, Glostrup, Denmark) for $30 \mathrm{~min}$ on ice. The cells were then washed with PBS and incubated with secondary antibody conjugated to fluorescein isothiocyanate (SigmaAldrich, Inc., St. Louis, MO, USA). The cells were washed again with PBS and resuspended in PBS containing $1 \%$ paraformaldehyde. The fluorescence intensity of the cells was detected by flow cytometry and analyzed quantitatively. All analyses were performed in triplicate in three separate experiments.

Immunohistochemistry. Mice were sacrificed as described above in the animal model studies, and tumors were resected to assess the expression of P-gp, glutathione S-transferase (GST), and topoisomerase II (topo II) proteins by immunohistochemistry according to a previously described method by Elias et al (10) with some modifications. Formalin-fixed specimens were embedded in paraffin using an embedding machine (EG1150H, Leica, Germany), and 5- $\mu$ m-thick tissue sections were cut using a histotome (Model 512; Leica). The expression of P-gp, GST, and topo II proteins was measured using an Ultra Sensitive ${ }^{\mathrm{TM}}$ SP kit (Fuzhou Maixin Biotechnology Development Co., Ltd., Fuzhou, Fujian, China). The sections were deparaffinized, and the antigens were recovered. For staining with antibodies against GST and topo II, the slides were incubated in preheated $0.05 \mathrm{M}$ Tris- $\mathrm{HCl}(\mathrm{pH} 7.6)$ containing $0.05 \%$ trypsin and $0.05 \% \mathrm{CaCl}_{2}$ for $5 \mathrm{~min}$ at $37^{\circ} \mathrm{C}$ before microwave treatment. The sections were incubated with hydrogen peroxide to block endogenous peroxidase and then incubated overnight at $4^{\circ} \mathrm{C}$ with antibody against P-gp, GST, or topo II $(1: 2000)$ as the primary antibody, followed by incubation with secondary antibody $(1: 2000)$ conjugated to streptavidin peroxidase. Color was developed with diamino- 
Table II. Effect of catechins on cell survival in doxorubicinresistant BEL-7404 cells and parental BEL-7404 cells in vitro, as determined by MTT assay $(n=9)$.

\begin{tabular}{ccc}
\hline & \multicolumn{2}{c}{ Cell survival rate (mean $\pm \mathrm{SD})$} \\
\cline { 2 - 3 } Catechin $(\mu \mathrm{g} / \mathrm{ml})$ & BEL-7404 & BEL-7404/DOX \\
\hline ECG & & \\
125 & $90.6 \pm 17.4$ & $98.5 \pm 21.3$ \\
250 & $81.3 \pm 3.9$ & $92.7 \pm 16.4$ \\
504 & $50.7 \pm 6.6$ & $76.4 \pm 12.9$ \\
1000 & $42.8 \pm 2.6$ & $70.3 \pm 8.6$ \\
2000 & $33.2 \pm 6.1$ & $65.2 \pm 5.8$ \\
EGCG & & \\
70 & $92.8 \pm 16.9$ & $94.3 \pm 11.5$ \\
140 & $80.3 \pm 9.7$ & $95.4 \pm 13.6$ \\
285 & $55.1 \pm 4.4$ & $85.6 \pm 9.7$ \\
560 & $47.1 \pm 9.3$ & $73.8 \pm 28.1$ \\
1120 & $37.4 \pm 8.6$ & $69.4 \pm 8.8$ \\
\hline
\end{tabular}

ECG, epicatechin gallate; EGCG, epigallocatechin gallate.

benzidine peroxidase substrate solution, and the sections were counterstained with hematoxylin. For the negative control, PBS was used instead of a primary antibody.

The immunohistochemical results were examined independently by two pathologists. All cell membranes and cytoplasm exhibiting a brown reaction product were considered positive. Nuclear staining, which was seen occasionally, was considered non-specific. The sections were examined under a microscope with image analysis (DMR+Q550; Leica) and a microphotography system (Vanox; Olympus, Japan) at low power to identify evenly labeled areas. The positive cells were counted and are reported as a percentage of the total cells evaluated. The results are expressed as the mean \pm SD of three independent counts.

Statistical analysis. The results are expressed as means and standard deviations (SD). Differences between groups were analyzed using Student's t-test, followed by variance analysis for comparisons among groups. A $\mathrm{P}<0.05$ was considered statistically significant.

\section{Results}

In vitro effects of DOX and catechins on cell proliferation in human hepatoma cells. To understand the effects of catechins on DOX antitumor activity in a murine model for DOXresistant HCC, we first characterized the DOX-resistant human HCC cell line BEL-7404/DOX and its parental sensitive cell line BEL-7404 in vitro. Based on MTT assays of cultured cells, the $\mathrm{IC}_{50}$ for DOX in the resistant BEL-7404/DOX cells was 38 times that in the parental BEL-7404 cells (36 vs. $0.94 \mu \mathrm{g} / \mathrm{ml}$, respectively).
Table III. Effect of catechins on DOX cytotoxicity in DOXresistant and parental hepatoma cells in vitro $(\mathrm{n}=9)$.

Cell survival rate (mean $\pm \mathrm{SD})$

\begin{tabular}{lcc}
\cline { 2 - 3 } Treatment $(\mu \mathrm{g} / \mathrm{ml})$ & BEL-7404 & BEL-7404/DOX \\
\hline Untreated control & 100 & 100 \\
DOX 0.8 & $53.6 \pm 4.9$ & $93.6 \pm 7.2$ \\
DOX 2.0 & $26.1 \pm 4.4$ & $77.2 \pm 8.5$ \\
ECG 60 + DOX 0.8/2.0 & $46.1 \pm 3.9^{\mathrm{b}}$ & $38.6 \pm 4.2^{\mathrm{b}}$ \\
EGCG 14 + DOX 0.8/2.0 & $42.3 \pm 5.7^{\mathrm{b}}$ & $29.4 \pm 3.8^{\mathrm{b}}$ \\
\hline
\end{tabular}

${ }^{\mathrm{a}} \mathrm{ECG}$ at $60 \mathrm{mg} / \mathrm{ml}$ and EGCG at $14 \mathrm{mg} / \mathrm{ml}$ were used; DOX was used at $0.8 \mathrm{mg} / \mathrm{ml}$ in BEL-7404 cells and at $2.0 \mathrm{mg} / \mathrm{ml}$ in BEL-7404/ DOX cells. ${ }^{b} \mathrm{P}<0.01$ vs. the DOX alone group. ECG, epicatechin gallate; EGCG, epigallocatechin gallate; DOX, doxorubicin.

We next examined the effect of the catechins ECG and EGCG on cell proliferation in both cell lines in vitro using the MTT assay. At concentrations $<100 \mu \mathrm{g} / \mathrm{ml}$, neither ECG nor EGCG was cytotoxic in either cell line. However, at ECG or EGCG concentrations $\geq 100 \mu \mathrm{g} / \mathrm{ml}$, the survival rate decreased with increasing catechin concentration in both cell lines (Table II). The $\mathrm{IC}_{50}$ values for ECG and EGCG in BEL-7404 cells were 508 and $260 \mu \mathrm{g} / \mathrm{ml}$, respectively. However, even at concentrations as high as 2,000 $\mu \mathrm{g} / \mathrm{ml}$, ECG did not reduce the survival of BEL-7404/DOX cells by $50 \%$. The same was true for EGCG, even at a concentration of $1,120 \mu \mathrm{g} / \mathrm{ml}$ (Table II). Hence, we were not able to determine the $\mathrm{IC}_{50}$ for ECG or EGCG in BEL-7404/DOX cells.

Catechins enhance chemosensitivity to DOX and increase DOX cytotoxicity in HCC cells in vitro. We tested the effects of ECG and EGCG on DOX antitumor activity in the resistant and sensitive HCC cell lines in vitro using the MTT assay. At non-toxic doses, both ECG $(60 \mu \mathrm{g} / \mathrm{ml})$ and EGCG $(14 \mu \mathrm{g} / \mathrm{ml})$ significantly increased DOX-dependent cell death in the two cell lines, with a greater enhancement in BEL-7404/DOX cells than in BEL-7404 cells (Table III). ECG and EGCG also enhanced sensitivity to DOX in both BEL-7404 and BEL-7404/DOX cells (Table IV). In BEL-7404/DOX cells, the $\mathrm{IC}_{50}$ for DOX was reduced from 36 to $2.3 \mu \mathrm{g} / \mathrm{ml}$ by ECG and to $1.9 \mu \mathrm{g} / \mathrm{ml}$ by EGCG, representing drug resistance reversals of 15.7- and 19.0-fold, respectively. The effects of both catechins on DOX antitumor activity were better than that of VPL $(0.28 \mu \mathrm{g} / \mathrm{ml})$, a known chemosensitizer used as the positive control in this experiment (Table IV).

Effect of EGCG and DOX on human HCC growth in an in vivo tumor xenograft model. Given that cell survival and proliferation were decreased in BEL-7404/DOX cells in vitro following exposure to catechins and DOX, we next evaluated the effects of low, middle, and high doses of EGCG in combination with DOX on HCC growth in an in vivo mouse model. The tumors in all three DOX plus EGCG (DE) groups 
Table IV. Toxicity of DOX and modulation of drug resistance by ECG, EGCG, and VPL in human hepatocellular carcinoma cells in vitro.

\begin{tabular}{lcccc}
\hline & \multicolumn{2}{c}{$\mathrm{IC}_{50}(\mu \mathrm{g} / \mathrm{ml})^{\mathrm{a}}$} & \multicolumn{2}{c}{ Reversal fold $^{\mathrm{b}}$} \\
\cline { 2 - 5 } Treatment & $\mathrm{BEL}-7404$ & $\mathrm{BEL}-7404 / \mathrm{DOX}$ & BEL-7404 & 1.0 \\
\hline DOX & $0.94 \pm 0.07$ & $36 \pm 4.8$ & 2.76 & 1.0 \\
ECG + DOX & $0.34 \pm 0.03^{\mathrm{d}}$ & $2.3 \pm 0.7^{\mathrm{c}}$ & 2.76 & 15.7 \\
EGCG + DOX & $0.34 \pm 0.08^{\mathrm{d}}$ & $1.9 \pm 0.2^{\mathrm{d}}$ & 2.0 & 19.0 \\
VPL + DOX & $0.46 \pm 0.07$ & $2.4 \pm 0.3$ & 15.0 \\
\hline
\end{tabular}

${ }^{\mathrm{a} C e l l}$ toxicity was measured as described in Materials and methods in response to increasing concentrations of DOX. ECG at $60 \mu \mathrm{g} / \mathrm{ml}$, EGCG at $14 \mu \mathrm{g} / \mathrm{ml}$, and VPL at $0.28 \mu \mathrm{g} / \mathrm{ml}$ were used in the experiments. ${ }^{b}$ Reversal fold was calculated as $\mathrm{IC}_{50}$ of DOX alone group divided by $\mathrm{IC}_{50}$ of $\mathrm{DOX}+$ catechin or DOX $+\mathrm{VPL}$. Data are presented as mean $\pm \mathrm{SD} ; \mathrm{n}=9$. ${ }^{\mathrm{c}} \mathrm{P}<0.01 \mathrm{vs}$. DOX alone; ${ }^{\mathrm{d}} \mathrm{P}<0.01 \mathrm{vs}$. DOX alone or $\mathrm{VPL}$ + DOX. DOX, doxorubicin; ECG, epicatechin gallate; EGCG, epigallocatechin gallate; VPL, verapamil.
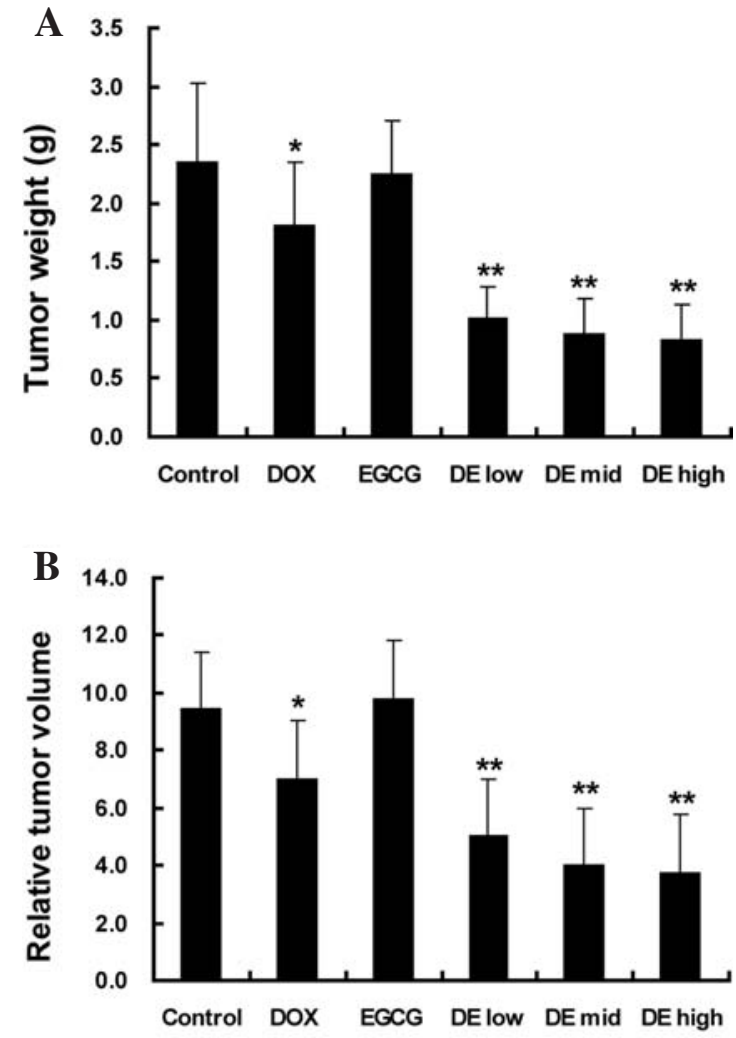

grew very slowly in vivo, with dimensions considerably smaller than those in the untreated control group or the DOX alone group (Fig. 2), even on day 22 of the study (Fig. 3). At the termination of the study, the differences in tumor mass and tumor weight between the DE groups and the control group or DOX alone group were marked $(\mathrm{P}<0.01)$, with the greatest effect observed at the highest EGCG dose (Fig. 3 and Table V). As shown in Table $\mathrm{V}$, the average tumor volumes on day 33

Figure 2. Enhancement by EGCG of DOX anticancer activity in xenograft tumors of living mice. BEL-7404/DOX human hepatoma cells $\left(5 \times 10^{7}\right)$ were transplanted subcutaneously on the right axilla of BALB/c nu/nu nude mice. After the tumors were established, the mice were divided into six groups $(n=10$ mice/group, 5 male and 5 female mice/group) and were injected with normal saline only (control), DOX alone ( $2 \mathrm{mg} / \mathrm{kg}$, q4d, ip; DOX), EGCG alone $(80 \mathrm{mg} / \mathrm{kg}, \mathrm{qd}$, ig; EGCG), or DOX combined with a lower dose of EGCG (40 mg/kg; qd, ig, DE low group), a middle dose of EGCG (80 mg/kg; qd, ig, DE mid group), or a higher dose of EGCG (160 mg/kg, qd, ig; DE high group), respectively. Mice were sacrificed 33 days later. Tumor weight (A) and relative tumor volume $(\mathrm{B})$ were determined. ${ }^{*} \mathrm{P}<0.05$ vs. the control group; ${ }^{* *} \mathrm{P}<0.01$ vs. the DOX alone group. (C) Photographs taken at the end of the experiment showing control mice and mice treated with DOX alone, EGCG alone, or the drug combinations (DOX + EGCG) as described above. Magnification, $\mathrm{x} 400$.

\section{C}

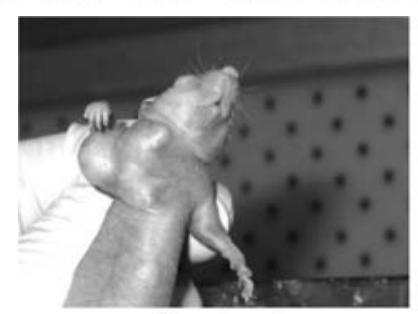

Control



DOX+EGCG Low

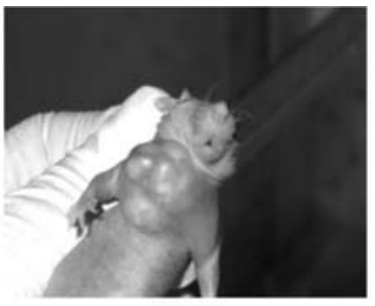

DOX

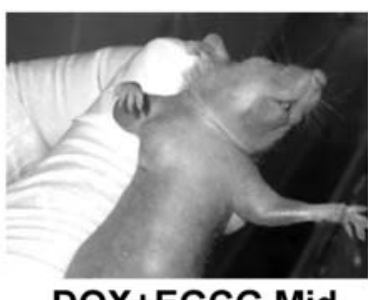

DOX+EGCG Mid

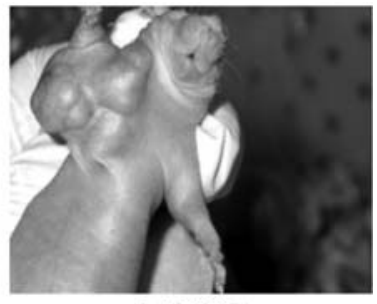

EGCG

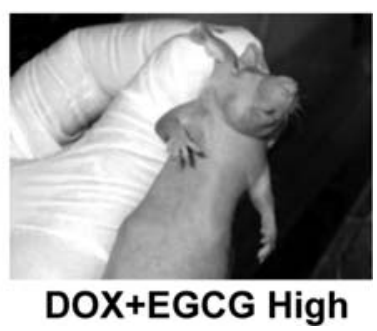




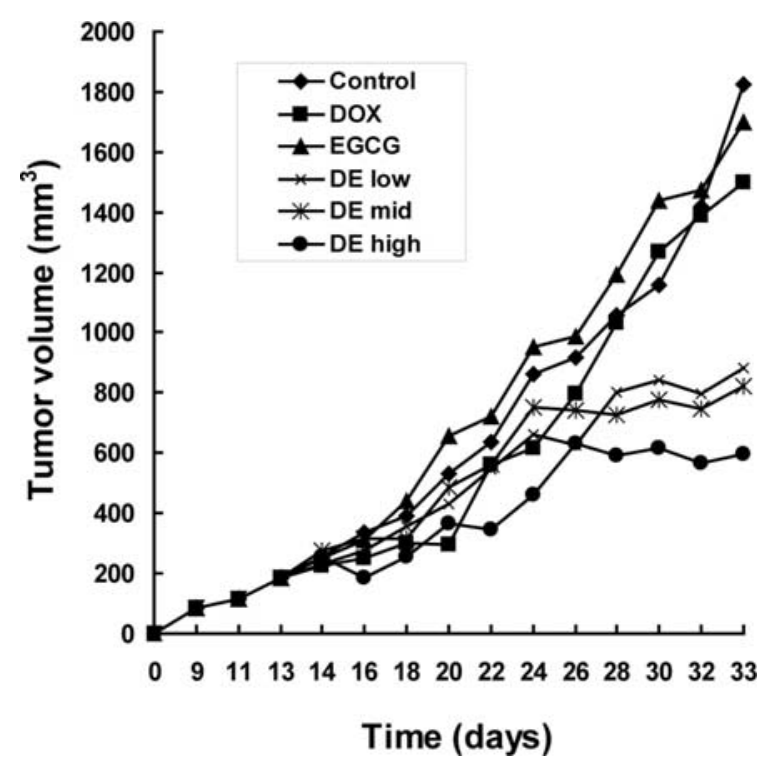

Figure 3. Enhancement by EGCG of DOX effect on the growth of human BEL-7404/DOX xenograft tumors in living mice. Xenograft tumors were established and treated with DOX and/or EGCG as described in Materials and methods. The inhibition of tumor growth in vivo was determined by measuring the tumor dimensions using calipers, every 3 days for up to 33 days. Mean tumor volume was calculated as width ${ }^{2} \mathrm{x}$ length $\mathrm{x} 0.52$. All measurements were performed in a coded, blinded fashion. Tumor growth curves in the different treatment groups are shown. DOX, doxorubicin; EGCG, epigallocatechin gallate; DE Low, DOX + EGCG 40 mg/kg; DE Mid, DOX + EGCG 80 mg/kg; DE High, DOX + EGCG $160 \mathrm{mg} / \mathrm{kg}$.

were 5.0, 4.0, and $3.7 \mathrm{~cm}^{3}$ in the DE Low, DE Mid, and DE High groups, respectively, whereas the tumor volumes in the control and DOX alone groups were 9.4 and $7.0 \mathrm{~cm}^{3}$, respectively. The tumor inhibition rates (TIRs) of the three combination groups ranged from 56.7 to $65.1 \%$ and were significantly higher than that of the DOX alone group $(\mathrm{P}<0.01)$.

To quantitate the interaction between EGCG and DOX antitumor activity, we calculated the q-value, which represents the interaction between two drugs for tumor inhibition, using the formula: $\mathrm{q}=\left(\mathrm{TIR}_{\mathrm{DE} \text { group }} / \mathrm{TIR}_{\mathrm{DOX} \text { alone group }}\right)+\left(1-\mathrm{TIR}_{\mathrm{DOX} \text { alone }}\right.$ group $) \times \mathrm{TIR}_{\mathrm{EGCG}}$ alone group. Generally, $\mathrm{q}>1.15$ indicates synergism, $\mathrm{q}=0.85-1.15$ indicates an additive effect, and $\mathrm{q}<0.85$ indicates antagonism. Using the TIR for the DE Mid group, a q-value of 2.74 was calculated, indicating a strong synergistic anticancer activity at a medium dose of EGCG $(80 \mathrm{mg} / \mathrm{kg}$, qd) and DOX in an in vivo tumor xenograph model for HCC.

We also monitored the toxicity of EGCG in mice and in human non-cancerous cells. At the doses tested, EGCG alone did not cause cytotoxicity in mouse splenic cells or in human HL-7721 hepatocyte cells (data not shown). Furthermore, the body weight of the mice did not significantly decrease, whether EGCG was administered alone or in combination with DOX; in fact, some mice gained weight during the experiments (Table V). No animal died during the entire study.

Catechins significantly increase intracellular accumulation of DOX in BEL-7404/DOX cells in vitro and in vivo. We next asked whether catechins increased DOX cytotoxicity and DOX antitumor activity in vitro and in vivo by enhancing intracellular accumulation of DOX. To evaluate the reversal of DOX resistance by catechins, we determined the intracellular accumulation of DOX in HCC cells. Co-treatment of BEL$7404 /$ DOX cells with various concentrations of DOX and $60 \mu \mathrm{g} / \mathrm{ml}$ of ECG or $14 \mu \mathrm{g} / \mathrm{ml}$ of EGCG in vitro resulted in 2.7- to 6.4-fold increases in intracellular DOX accumulation compared with that in tumor cells treated with DOX alone, with EGCG having a greater effect and efficacy than ECG (Table VI). Similarly, EGCG at $40-160 \mathrm{mg} / \mathrm{kg}$ significantly enhanced intracellular DOX accumulation in BEL-7404/DOX xenograft tumor cells (Fig. 4). The DOX concentrations in xenograft tumor tissues from living mice treated with the lower, middle, and higher doses of EGCG were 1.604 \pm 0.317 , $2.095 \pm 0.585$, and $2.229 \pm 0.463 \mu \mathrm{g} / \mathrm{g}$ tumor tissue, respectively; these concentrations were all significantly higher $(\mathrm{P}<0.01)$ than that in the DOX alone group $(1.046 \pm 0.35 \mu \mathrm{g} / \mathrm{g}$ tumor tissue; Fig. 4).

Catechins enhance the accumulation of rhodamine 123 in HCC cells. We investigated whether the catechin-induced increase in DOX concentration was attributable to a reduction in the Pgp-mediated efflux of DOX in BEL-7404/DOX cells. Rhodamine 123 (rho123), a fluorescent molecule, is an

Table V. Effect of EGCG on DOX anticancer activity in BEL-7404/DOX xenograft tumors.

\begin{tabular}{lccccccc}
\hline $\begin{array}{l}\text { Treatment } \\
\text { group }\end{array}$ & $\begin{array}{c}\text { Body weight, } \\
\text { pre-dose }(\mathrm{g})\end{array}$ & $\begin{array}{c}\text { Body weight, } \\
\text { post-dose }(\mathrm{g})\end{array}$ & $\begin{array}{c}\text { Body weight } \\
\text { loss }(\%)\end{array}$ & $\begin{array}{c}\text { Tumor } \\
\text { weight }(\mathrm{g})\end{array}$ & $\begin{array}{c}\text { Tumor } \\
\text { inhibition }(\%)\end{array}$ & $\begin{array}{c}\text { Tumor } \\
\text { volume }\left(\mathrm{cm}^{3}\right)\end{array}$ & $\begin{array}{c}\text { Relative tumor } \\
\text { growth rate }(\%)\end{array}$ \\
\hline Control & $24.1 \pm 1.6$ & $27.5 \pm 1.8$ & 0 & $2.35 \pm 0.67$ & 0 & $9.4 \pm 1.2$ & 100 \\
DOX & $23.2 \pm 0.4$ & $23.1 \pm 1.2^{\mathrm{a}}$ & 0.6 & $1.81 \pm 0.54^{\mathrm{a}}$ & 23.0 & $7.0 \pm 1.0^{\mathrm{a}}$ & 74.4 \\
EGCG & $23.1 \pm 1.5$ & $25.8 \pm 2.8$ & 0 & $2.24 \pm 0.45$ & 4.6 & $9.8 \pm 1.3$ & 103.9 \\
DE Low & $23.1 \pm 0.9$ & $23.1 \pm 1.2$ & 1.3 & $1.02 \pm 0.27^{\mathrm{b}}$ & 56.7 & $5.0 \pm 1.4^{\mathrm{b}}$ & 53.0 \\
DE Mid & $24.2 \pm 0.4$ & $21.9 \pm 2.0$ & 4.4 & $0.89 \pm 0.29^{\mathrm{b}}$ & 62.2 & $4.0 \pm 0.9^{\mathrm{b}}$ & 42.2 \\
DE High & $23.0 \pm 0.3$ & $24.1 \pm 2.6$ & 0 & $0.82 \pm 0.31^{\mathrm{b}}$ & 65.1 & $3.7 \pm 0.9^{\mathrm{b}}$ & 39.7 \\
\hline
\end{tabular}

Data are presented as mean $\pm \mathrm{SD} ; \mathrm{n}=10$. ${ }^{\mathrm{P}}<0.01$ vs. the control group; ${ }^{\mathrm{b}} \mathrm{P}<0.01$ vs. the $\mathrm{DOX}$ alone group or the control group. DOX, doxorubicin; EGCG, epigallocatechin gallate; DE Low, DOX + EGCG $40 \mu \mathrm{g} / \mathrm{ml}$; DE Mid, DOX + EGCG $80 \mu \mathrm{g} / \mathrm{ml}$; DE High, DOX + EGCG $160 \mu \mathrm{g} / \mathrm{ml}$. 
Table VI. Effect of catechins on intracellular accumulation of DOX in vitro in cultured hepatoma cells.

Intracellular DOX concentration $\left(\mu \mathrm{g} / 10^{8} \text { cells }\right)^{\mathrm{a}}$

\begin{tabular}{lcccc}
$\begin{array}{l}\text { DOX } \\
(\mu \mathrm{g} / \mathrm{ml})\end{array}$ & $\begin{array}{c}\text { ECG } \\
(\mu \mathrm{g} / \mathrm{ml})\end{array}$ & $\begin{array}{c}\text { EGCG } \\
(\mu \mathrm{g} / \mathrm{ml})\end{array}$ & DOX + catechin & DOX alone \\
\hline 1.2 & 60 & 0 & $2.04 \pm 0.07^{\mathrm{b}}$ & $0.76 \pm 0.02$ \\
2.5 & 60 & 0 & $2.82 \pm 0.12^{\mathrm{b}}$ & $0.94 \pm 0.04$ \\
3.6 & 60 & 0 & $4.05 \pm 0.28^{\mathrm{b}}$ & $1.47 \pm 0.07$ \\
4.8 & 60 & 0 & $5.33 \pm 0.51^{\mathrm{b}}$ & $2.15 \pm 0.05$ \\
1.2 & 0 & 14 & $4.17 \pm 0.38^{\mathrm{b}}$ & $0.93 \pm 0.08$ \\
2.5 & 0 & 14 & $6.24 \pm 0.55^{\mathrm{b}}$ & $1.02 \pm 0.09$ \\
3.6 & 0 & 14 & $8.73 \pm 0.73^{\mathrm{b}}$ & $1.36 \pm 0.14$ \\
4.8 & 0 & 14 & $9.28 \pm 0.59^{\mathrm{b}}$ & $2.55 \pm 0.17$ \\
\hline
\end{tabular}

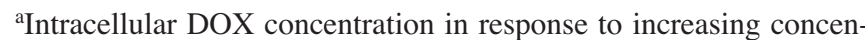
trations of DOX alone or DOX + catechins was measured as described in Materials and methods. Data are presented as mean $\pm \mathrm{SD} ; \mathrm{n}=3$. ${ }^{\mathrm{b}} \mathrm{P}<0.01$ vs. DOX alone. DOX, doxorubicin; ECG, epicatechin gallate; EGCG, epigallocatechin gallate.

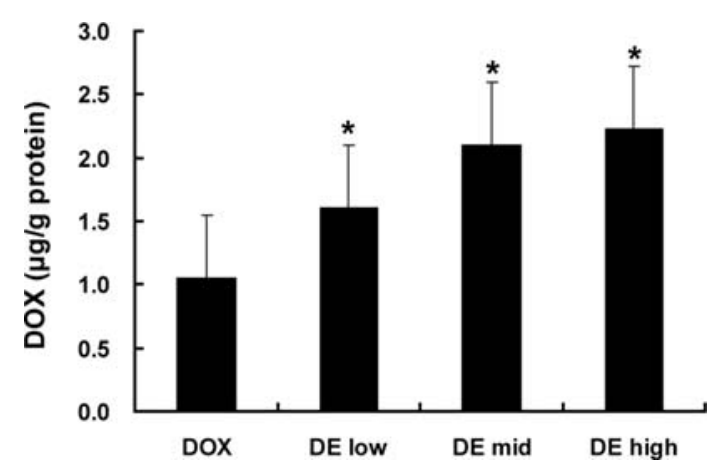

Figure 4. Enhancement by EGCG of the intracellular accumulation of DOX in BEL-7404/DOX xenograft tumors in living mice. Xenograft tumors were established and treated with DOX and/or EGCG as described in the legend for Fig. 2. Mice were sacrificed on day 33 after treatment. Tumors were resected to determine DOX intracellular accumulation by fluorospectrophotometry, as described in Materials and methods. A graph representing the analysis of intracellular DOX fluorescence is shown. Data are presented as mean \pm SD for at least three independent experiments. Bars indicate SD. ${ }^{*} \mathrm{P}<0.05$ vs. the DOX alone group. DOX, doxorubicin; EGCG, epigallocatechin gallate; DE Low, DOX + EGCG $40 \mathrm{mg} / \mathrm{kg}$; DE Mid, DOX + EGCG $80 \mathrm{mg} / \mathrm{kg}$; DE High, DOX + EGCG $160 \mathrm{mg} / \mathrm{kg}$.

excellent substrate for P-gp, and cells that overexpress P-gp fail to accumulate rho123 because of enhanced drug efflux activity by P-gp. Therefore, rho123 accumulation was used as an imaging agent to evaluate the inhibition of P-gp activity at the single-cell level. To determine the effect of catechins on the function of P-gp, the intracellular accumulation of rho123 was examined by flow cytometry. Without prior treatment with catechins, the added rho123 was significantly accumulated in sensitive BEL-7404 cells, but not in resistant BEL-7402/DOX cells (Table VII). Pre-incubation of BEL-7404 and BEL-7404/ DOX cells with either ECG or EGCG led to a marked increase in rho123 accumulation in BEL-7404/DOX cells (23.1- to 29.1-fold increase) and a lesser increase of only 22.6 to $39.3 \%$ in the accumulation of rho123 in BEL-7404 cells (Table VII). The accumulation of rho123 was much higher with EGCG than with ECG.

Catechins inhibit P-glycoprotein expression in DOX-resistant HCC cells in vitro and in xenograft tumors. The rhodamine 123 (rho123) retention described above suggested that catechins altered P-gp function in HCC cells. We examined whether this occurred via the inhibition of P-gp expression in our system by using an immunohistochemical assay to measure P-gp expression in BEL-7404/DOX xenograft tumor tissues from nude mice. Pgp-specific staining was seen mainly on the plasma membrane surfaces of the cells, and specific positive staining of P-gp was observed in most of the resistant BEL-7404/DOX cells. However, the expression of P-gp was markedly inhibited in mice treated with EGCG $(40-160 \mathrm{mg} / \mathrm{kg})$ compared with mice receiving DOX alone (Table VIII). To check the specificity of P-gp immunostaining in BEL-7404/ DOX cells, we also assessed the expression of GST and topo II proteins in the tumor tissues. As seen in Table VIII, EGCG significantly increased topo II protein expression and did not alter GST protein expression compared with the expression levels in the DOX alone group, indicating that the cell staining for P-gp was specific in our experiments.

To confirm the inhibitory effect of EGCG on P-gp expression in xenograft tumors of living mice, we analyzed P-gp expression using a FITC-conjugated antibody and flow cytometry. As shown in Fig. 5, in the BEL-7404/DOX cells treated with DOX alone, the fluorescence intensity was high, representing a higher level of P-gp expression. Catechin-treated cells showed significantly decreased fluorescence intensity, indicating reduced P-gp expression (Fig. 5). Compared with ECG, EGCG had a greater inhibitory effect on P-gp expression (Fig. 5).

Inhibitory effect of catechins on the expression of drug resistance genes in vitro and in xenograft tumors. As P-gp is the direct product of the MDRl gene, we wondered whether the inhibitory effect of catechins on the P-gp level in tumor tissues occurred through the suppression of MDRl expression. To address this question, semi-quantitative RT-PCR was used to detect MDR1 mRNA expression in BEL-7404/DOX cells. As shown in Table IX, after treatment of BEL-7404/DOX cells with ECG or EGCG in vitro, MDR1 mRNA expression was significantly decreased compared with that in untreated cells or cells treated with DOX alone $(\mathrm{P}<0.05)$. Compared with the effect of VPL, a known P-gp inhibitor, both catechins reduced MDR1 mRNA expression to a greater extent, and EGCG produced the greatest inhibition (Table IX). Similar data were observed in xenograft tumor tissues (Fig. 6). PCR analysis indicated a concentration-dependent reduction in MDR1 mRNA in BEL-7404/DOX cells from the in vivo mouse model administered EGCG (Table X). To confirm the specificity of EGCG-mediated inhibition of MDR1 expression, the mRNA expression of multidrug resistance-associated protein $1(M R P 1)$, lung resistance-related protein $(L R P)$, and 
Table VII. Effect of catechins on intracellular retention of rhodamine 123 in DOX-resistant and parental HCC cells.

\begin{tabular}{|c|c|c|c|}
\hline \multirow[b]{2}{*}{ HCC cell line } & \multicolumn{3}{|c|}{ Treatment } \\
\hline & DOX & $\mathrm{ECG}+\mathrm{DOX}$ & $\mathrm{EGCG}+\mathrm{DOX}$ \\
\hline BEL-7404 & $2270.58 \pm 704.59$ & $2784.2 \pm 1028.74^{a}$ & $3161.91 \pm 1458.92^{\mathrm{a}}$ \\
\hline BEL-7404/DOX & $124.36 \pm 67.53$ & $2871.42 \pm 978.08^{\mathrm{a}}$ & $3618.66 \pm 1754.26^{a}$ \\
\hline
\end{tabular}

Table VIII. Effect of EGCG on P-gp, GST, and topo II protein expression in BEL-7404/DOX xenograft tumors, as determined by immunohistochemical analysis.

\begin{tabular}{llll}
\hline Treatment & P-gp (\%) & GST- $\alpha(\%)$ & Topo II (\%) \\
\hline Control & $80.2 \pm 9.2$ & $50.7 \pm 5.5$ & $18.4 \pm 1.3$ \\
DOX & $84.0 \pm 7.2$ & $78.0 \pm 3.5^{\mathrm{a}}$ & $17.3 \pm 2.1$ \\
EGCG & $42.0 \pm 7.9^{\mathrm{a}}$ & $56.6 \pm 4.0$ & $32.9 \pm 1.6^{\mathrm{a}}$ \\
DE Low & $53.5 \pm 6.0^{\mathrm{b}}$ & $76.5 \pm 3.8$ & $30.5 \pm 3.7^{\mathrm{b}}$ \\
DE Mid & $44.7 \pm 8.3^{\mathrm{b}}$ & $78.3 \pm 4.7$ & $32.4 \pm 2.9^{\mathrm{b}}$ \\
DE High & $40.7 \pm 6.8^{\mathrm{b}}$ & $81.2 \pm 4.2$ & $37.7 \pm 2.8^{\mathrm{b}}$ \\
\hline
\end{tabular}

Data are percentage of total cells evaluated by immunohistochemistry as described in Materials and methods and are presented as mean \pm $\mathrm{SD} ; \mathrm{n}=3$. ${ }^{\mathrm{a}} \mathrm{P}<0.01$ vs. the control group; ${ }^{\mathrm{b}} \mathrm{P}<0.01$ vs. the $\mathrm{DOX}$ alone group or the control group. DOX, doxorubicin; EGCG, epigallocatechin gallate; DE Low, DOX + EGCG $40 \mathrm{mg} / \mathrm{kg}$; DE Mid, DOX + EGCG $80 \mathrm{mg} / \mathrm{kg}$; DE High, DOX + EGCG $160 \mathrm{mg} / \mathrm{kg}$. GST, glutathione S-transferase; P-gp, P-glycoprotein; Topo II, topoisomerase II.
Table IX. Inhibitory effect of catechins and verapamil on MDR1 mRNA expression in human BEL-7404/DOX hepatoma cells in vitro.

\begin{tabular}{lc}
\hline Treatment & Relative MDR1 mRNA level ${ }^{\mathrm{a}}$ \\
\hline Untreated control & $2.85 \pm 0.74$ \\
DOX alone & $2.67 \pm 0.89$ \\
DOX + ECG & $1.83 \pm 0.65^{\mathrm{b}}$ \\
DOX + EGCG & $1.56 \pm 0.34^{\mathrm{b}}$ \\
DOX + VPL & $1.97 \pm 0.08^{\mathrm{b}}$ \\
\hline
\end{tabular}

DOX at $1.2 \mu \mathrm{g} / \mathrm{ml}$, ECG at $60 \mu \mathrm{g} / \mathrm{ml}$, EGCG at $14 \mu \mathrm{g} / \mathrm{ml}$, and VPL at $0.28 \mu \mathrm{g} / \mathrm{ml}$ were used in the experiments. Relative MDR1 mRNA expression in response to DOX alone, DOX + catechins, or DOX + VPL treatment for $36 \mathrm{~h}$ was assessed by semi-quantitative RT-PCR analysis as described in Materials and methods. ${ }^{\text {aNormalized to }}$ $\beta_{2}$-MG. Data are presented as mean $\pm \mathrm{SD} ; \mathrm{n}=6 .{ }^{\mathrm{b}} \mathrm{P}<0.05$ vs. the DOX alone group or the control group. DOX, doxorubicin; ECG, epicatechin gallate; EGCG, epigallocatechin gallate; MDR1, multidrug resistance 1; VPL, verapamil.
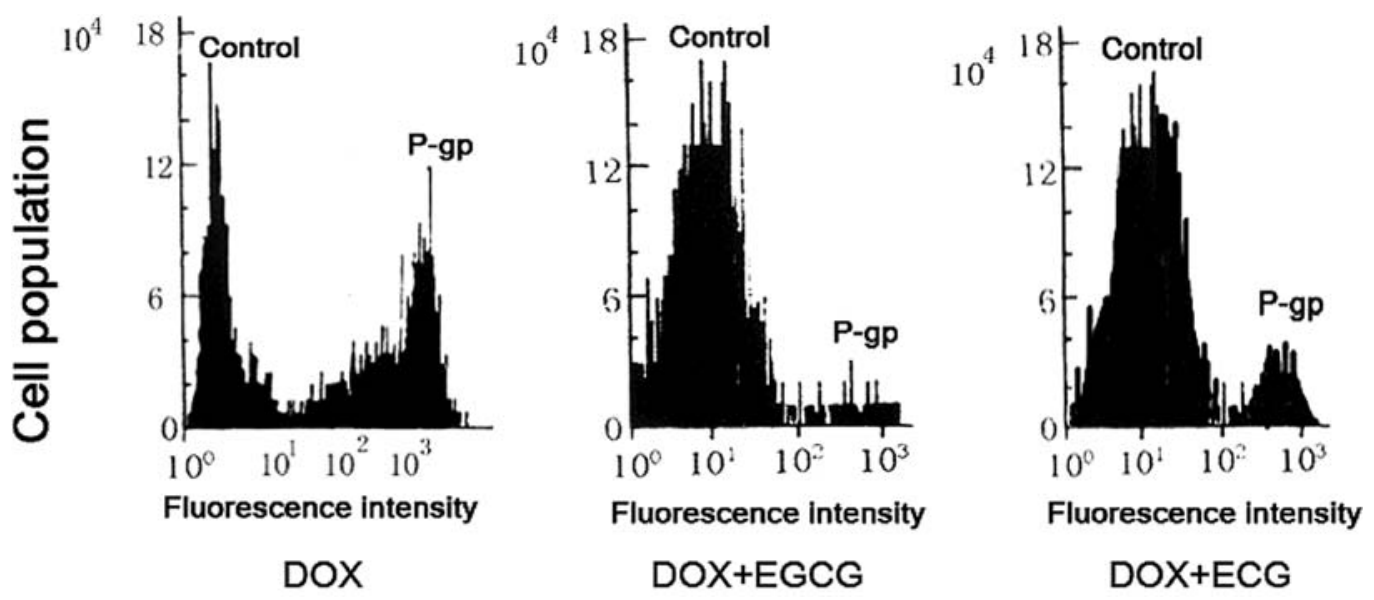

Figure 5. Inhibition by catechins of P-glycoprotein expression in human BEL-7404/DOX hepatoma cells in vitro, as assessed by flow cytometry. BEL-7404/DOX cells were treated with DOX alone or in combination with catechins, as described in Materials and methods. The inhibition of P-glycoprotein expression was determined by flow cytometry. Shown is a representative result from one of three independent experiments that demonstrated similar findings. DOX, doxorubicin; ECG, epicatechin gallate; EGCG, epigallocatechin gallate; P-gp, P-glycoprotein. 


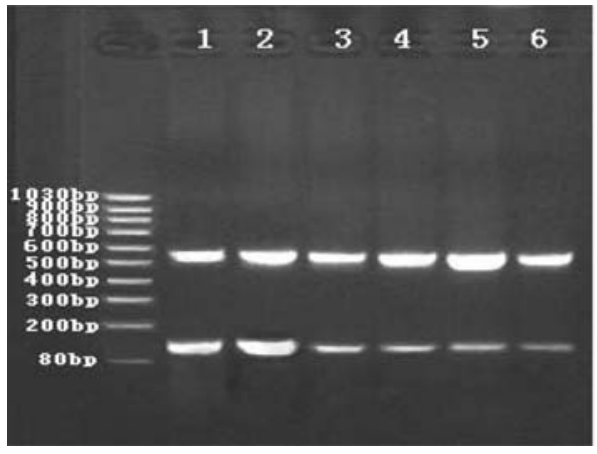

$\beta$-actin

MDR1

Figure 6. Reverse-transcription polymerase chain reaction (RT-PCR) analysis of the MDR1 mRNA expression level in BEL-7404/DOX xenograft tumors in nude mice. Xenograft tumors were established and treated with DOX and/or EGCG as described in the legend to Fig. 2. Mice were sacrificed on day 33 after treatment. Tumors were resected to determine MDR1 mRNA expression by semi-quantitative RT-PCR, as described in Materials and methods. Shown is a photograph representing the analysis of MDR1 mRNA expression in one of three independent experiments. Corresponding numeric data are shown in Table X. Lane 1, untreated control; lane 2, DOX alone; lane 3, EGCG alone; lane 4, DE Low; lane 5, DE Mid; lane 6, DE High. DOX, doxorubicin; EGCG, epigallocatechin gallate; DE Low, DOX + EGCG 40 mg/ml; DE Mid DOX + EGCG 80 mg/ml; DE High, DOX + EGCG 160 mg/kg.

hypoxia-inducible factor- $1 \alpha$ (HIF- $1 \alpha$ ) was also determined. We chose these genes because MDR frequently results from the inappropriate expression of drug resistance genes such as these. Following coadministration of DOX and EGCG in the in vivo tumor model, HIF- $1 \alpha$ mRNA expression was significantly reduced compared with that after DOX treatment alone $(\mathrm{P}<0.05$ or $<0.01)$, whereas the expression of MRP1 mRNA and LRP mRNA was not significantly changed $(\mathrm{P}>0.05)$ (Table $\mathrm{X}$ and Fig. 7). These data suggest that transcriptional downregulation of MDR1 gene expression by catechins may be responsible for the reduced expression of $\mathrm{P}-\mathrm{gp}$ in BEL-7404/DOX hepatoma cells in vitro and in vivo.

\section{Discussion}

HCC is one of the most common cancers worldwide and has an extremely poor prognosis $(1,2,11,12)$. DOX is the first-line drug for the treatment of HCC; however, both intrinsic and
Table X. Effect of EGCG on mRNA expression of several drug resistance-related genes in BEL-7404/DOX xenograft tumors.

\begin{tabular}{lcccc}
\hline & \multicolumn{4}{c}{ Relative mRNA level of gene expression } \\
\cline { 2 - 5 } Treatment & MDR1 & LRP & MRP1 & HIF-1 $\alpha$ \\
\hline Control & $0.92 \pm 0.15$ & $0.56 \pm 0.09$ & $0.64 \pm 0.09$ & $1.73 \pm 0.22$ \\
DOX & $1.09 \pm 0.14^{\mathrm{a}}$ & $0.66 \pm 0.11$ & $0.66 \pm 0.15$ & $1.53 \pm 0.12^{\mathrm{a}}$ \\
EGCG & $0.42 \pm 0.12^{\mathrm{b}}$ & $0.60 \pm 0.12$ & $0.63 \pm 0.13$ & $1.68 \pm 0.35$ \\
DE Low & $0.55 \pm 0.15^{\mathrm{d}}$ & $0.69 \pm 0.12$ & $0.70 \pm 0.14$ & $1.34 \pm 0.15^{\mathrm{c}}$ \\
DE Mid & $0.45 \pm 0.13^{\mathrm{d}}$ & $0.68 \pm 0.13$ & $0.68 \pm 0.11$ & $1.31 \pm 0.12^{\mathrm{d}}$ \\
DE High & $0.41 \pm 0.11^{\mathrm{d}}$ & $0.66 \pm 0.14$ & $0.61 \pm 0.10$ & $1.22 \pm 0.26^{\mathrm{d}}$ \\
\hline
\end{tabular}

Normalized to $B$-actin. Data are presented as mean $\pm \mathrm{SD} ; \mathrm{n}=6$. ${ }^{\mathrm{a}} \mathrm{P}<0.05$; and ${ }^{\mathrm{b}} \mathrm{P}<0.01$ vs. the control group; ${ }^{\mathrm{C}} \mathrm{P}<0.05$; and ${ }^{\mathrm{d}} \mathrm{P}<0.01$ vs. the DOX alone group. Relative mRNA expression was assessed by semi-quantitative RT-PCR analysis as described in Materials and methods. DOX, doxorubicin; EGCG, epigallocatechin gallate; DE Low, DOX + EGCG 40 mg/kg; DE Mid, DOX + EGCG 80 mg/kg; DE High, DOX + EGCG $160 \mathrm{mg} / \mathrm{kg}$. MDR1, multidrug resistance 1; LRP, lung resistance-related protein; MRP1, multidrug resistanceassociated protein $1 ; \mathrm{HIF}-1 \alpha$, hypoxia-inducible factor- $1 \alpha$.

acquired MDR limit its use in HCC chemotherapy. Increasing the DOX dosage is not a practical approach because of the associated toxicity and side effects. Identifying effective MDR modulators (also called MDR inhibitors, chemosensitizers, or reversal agents) to combine with DOX therapy has been a promising strategy against clinical MDR in HCC. A number of natural and synthetic compounds have been tested for their ability to reverse MDR. Unfortunately, most have failed in clinical trials, mainly due to their insufficient MDR reversal potency at a tolerated dosage, solubility limitations, or unacceptable side effects $(13,14)$. Therefore, the search for novel and more potent MDR modulators with fewer side effects and lower toxicity continues to be a high priority for successful chemotherapy of HCC patients with MDR.

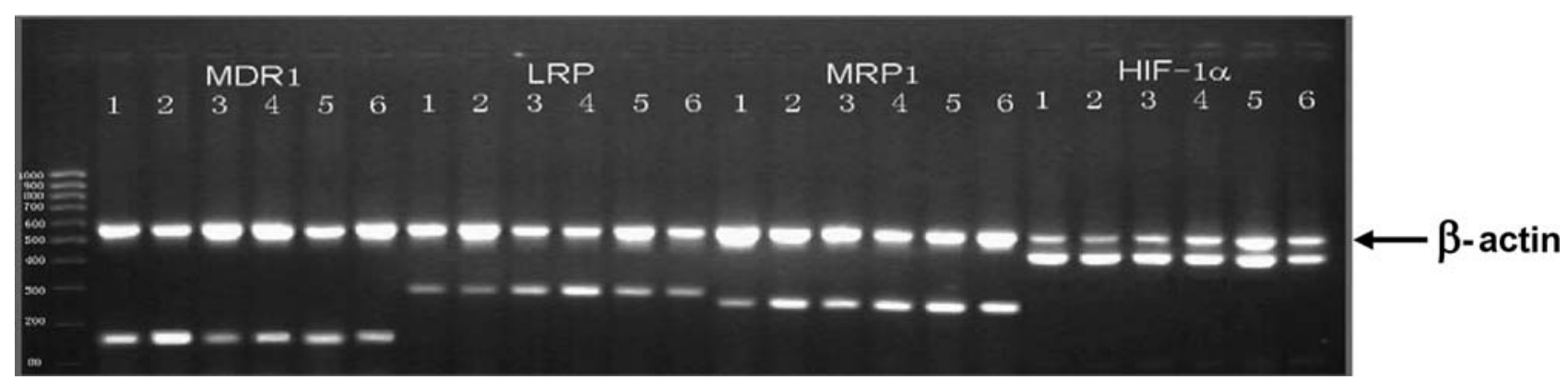

Figure 7. The mRNA expression of drug resistance-related genes in BEL-7404/DOX xenograft tumors, determined by semi-quantitative reverse-transcription polymerase chain reaction (RT-PCR). Xenograft tumors were established and treated with DOX and/or EGCG, as described in the legend to Fig. 2. Mice were sacrificed on day 33 after treatment. Tumors were resected to determine mRNA expression of four drug resistance-related genes by semi-quantitative RT-PCR, as described in Materials and methods. A photograph showing the mRNA expression of MDR1 (157 bp), LRP (285 bp), MRP1 (256 bp), and HIF-1 $\alpha$ (459 bp) is shown from one of three independent experiments. Corresponding numeric data are shown in Table X. Lane 1, untreated control; lane 2, DOX alone; lane 3, EGCG alone; lane 4, DE Low; lane 5, DE Mid; lane 6, DE High. DOX, doxorubicin; EGCG, epigallocatechin gallate; DE Low, DOX + EGCG 40 mg/kg; DE Mid, DOX + EGCG $80 \mathrm{mg} / \mathrm{kg}$; DE High, DOX + EGCG $160 \mathrm{mg} / \mathrm{kg}$. 
In the present study, green tea catechins increased the chemosensitivity to DOX in MDR liver cancer cells, even at their non-toxic concentrations. Specifically, ECG and EGCG, the most active polyphenolic compounds isolated from green tea, potently enhanced the susceptibility to DOX cytotoxicity in the resistant HCC cell line and significantly inhibited BEL-7404/DOX tumor growth in nude mice. The efficacy of both catechins was greater than that of VPL, and EGCG was more effective than ECG in reversing DOX resistance in vitro. Although the underlying mechanism explaining the difference in efficacy between ECG and EGCG is not clear, it may be related to a difference in chemical structure between the two catechins, as EGCG has one more phenyl hydroxyl group than ECG (Fig. 1). The hybrid effect between the aromatic ring and the hydroxyl group in the structure of EGCG makes this $-\mathrm{OH}$ group a better proton donor, and would make EGCG a more active compound and more potent antioxidant than ECG, thus accounting for its greater efficacy in conferring susceptibility to DOX in liver cancer.

The mechanism of drug resistance in liver cancer is far from fully understood. Biochemically, MDR modulators increase drug-induced antitumor activity through two mechanisms. The first mechanism comprises the inhibition of the intracellular metabolism of an antitumor agent, which leads to an increase in antitumor activity $(15,16)$. The second mechanism comprises a change in the drug transport across the cell membrane, which leads to an increase in antitumor activity via elevation of the drug concentration in the tumor $(17,18)$. The increases in DOX antitumor activity by catechins are involved in the second mechanism. We showed that EGC and EGCG increased the DOX concentrations in HCC cells in both in vitro and in vivo systems. Thus, it is suggested that ECG and EGCG may enhance DOX anticancer activity and increase intracellular DOX accumulation in HCC through the inhibition of DOX efflux.

A reduced intracellular concentration of chemotherapeutics is a major cause of MDR. It is a widely held hypothesis that intracellular levels of antitumor drugs are reduced below lethal thresholds by active extrusion through the operation of ATP-dependent pumps. P-gp, a 170-kDa glycoprotein, has been shown to mediate the efflux of various chemotherapeutic agents, including DOX $(19,20)$. Several modulators such as VPL have been reported to overcome MDR by inhibiting the cellular efflux of anticancer drugs (20). In the present study, the accumulations of DOX and rhodamine 123 were measured to assess catechin-induced inhibition of P-gp function. ECG and EGCG were very potent at reversing an accumulation deficit and at blocking the cellular efflux of two P-gp substrates, DOX and rhodamine 123. Thus, we propose that catechins augment DOX antitumor activity and reverse MDR by inhibiting the cellular efflux function of P-gp, thereby increasing the intracellular accumulation of the anticancer agent.

P-gp is encoded by the MDR1 gene, and our RT-PCR results showed that the level of MDR1 mRNA expression was higher in BEL-7404/DOX cells than in BEL-7404 cells. We believe that the overexpression of the MDR1 gene contributes to MDR in BEL-7404/DOX cells. Thus, if catechin-enhanced DOX intracellular concentration were due to reduced P-gp capacity, then catechin administration may downregulate
MDR1 mRNA expression and the P-gp protein level. Indeed, our RT-PCR data demonstrated that MDR1 mRNA expression was significantly inhibited by EGCG, and our quantitative analysis of P-gp by fluorescence-activated cell sorting and immunohistochemistry indicated that ECG and EGCG treatments markedly decreased the level of P-gp in DOX-resistant HCC cells. These data suggest that catechins enhance chemosensitivity to DOX and increase cytotoxicity of DOX by downregulating MDR1 gene expression and suppressing P-gp pump function in our model system.

In addition to P-gp, many other mechanisms have been implicated in MDR, and several of these with known clinical significance are under intensive investigation. First, decreased influx and increased efflux of drugs or enhanced activity of enzymes in the glutathione detoxification system can result in reduced drug accumulation. Genes such as $M D R 1, M R P 1$, $L R P$, and GST are involved in this process $(21,22)$. Second, increased DNA repair capacity and enhanced tolerance to DNA damage or cytotoxins can lead to cancer cell survival. Changes in the level or activity of hMLH1/hMSH2, ERCC, HIF-1 $\alpha$, or topoisomerases I/II may be involved in these mechanisms (23). Third, abnormalities in signaling proteins such as p53, p2 $1^{\mathrm{WAF} 1}, \mathrm{p} 27^{\mathrm{Kip} 1}, \mathrm{XIAP}, \mathrm{PI} 3 \mathrm{~K}$, caspase-9/3, Akt, JNK1, ERK1/2, and PKC (24-26) can interfere with intracellular signal transduction pathways at any point, from the primary damage to DNA or microtubules to the eventual death of the cell. Finally, dysfunction of apoptotic genes such as those for $\mathrm{Bcl}, \mathrm{Bax} / \mathrm{Bak} / \mathrm{Bad}$, or Fas/Fas-L can decrease apoptosis (27).

In the present study, we investigated some major upstream proteins such as MDR1, LRP, MRP1, HIF-1 $\alpha$, topo II, and GST- $\alpha$ in a search for commonly occurring mechanisms in chemoresistant HCC cells. MRP1 is a member of the ABC superfamily of membrane transport proteins, and overexpression of MRP1 has been postulated to reduce intracellular accumulation and alter intracellular distribution of antitumor agents. LRP is a transport protein that localizes in the nuclear membrane and nuclear pore complex. Its overexpression may induce MDR by changing the endonuclear distribution of drugs. On the other hand, GSTs are a family of enzymes contributing to phase I and/or phase II biotransformation of drugs. They may also bind toxins and function as transport proteins. Our RT-PCR and immunohistochemical results indicated no obvious alterations in MRP1, LRP, or GST- $\alpha$ expression in BEL-7404/DOX cells concurrently treated with DOX and EGCG, compared with cells treated with DOX only. Thus, these three proteins may not be important in increasing the intracellular DOX concentration in response to EGCG.

HIF- $1 \alpha$ is a transcription factor induced by low oxygen conditions and is found at high levels in malignant solid tumors, but not in normal tissues or slow-growing tumors. In fast-growing tumors, HIF- $1 \alpha$ plays crucial roles in the activation of numerous cellular processes, including cell immortalization, cell growth and survival, invasion/metastasis, angiogenesis, resistance to chemotherapy, and overexpression of drug efflux membrane pumps $(28,29)$. A recent report has shown that artemisinin induces DOX resistance by decreasing DOX accumulation and cytotoxicity in human colon cancer cells through the activation of HIF-1 $\alpha$ and P-gp overexpression 
(30). Lau and coworkers have shown in an orthotropic HCC model that combining blockade of HIF-1 $\alpha$ activity and ischemic hypoxia significantly enhanced the efficacy of chemotherapy, leading to the suppression of tumor growth and prolongation of animal survival; this suggests that blockade of HIF- $1 \alpha$ autocrine signaling may enhance the chemosensitivity of liver cancer cells under hypoxic conditions (31). Harris and colleagues reported that high expression levels of HIF-1 $\alpha$ were associated with a low rate of complete response to photodynamic therapy in early esophageal cancer (32). Intriguingly, we found that HIF- $1 \alpha$ mRNA expression was downregulated in chemoresistant HCC xenografts following the coadministration of EGCG and DOX, indicating an inverse correlation between the HIF-1 $\alpha$ level and the anticancer activity of EGCG and DOX in combination. This therapeutic combination was also associated with the downregulation of MDR1 expression and reduction of the $\mathrm{P}$-gp level. Although these findings suggest that HIF-1 $\alpha$ is involved in the catechin-induced increase in DOX chemosensitivity in our model, its role in this process and whether it participates in MDR1- and P-gp-mediated MDR are not yet clear. Therefore, the role and mechanism of HIF-1 $\alpha$ in catechin-mediated enhancement of DOX anticancer activity in liver cancer remain to be determined.

Type II topoisomerases (topo II; EC 5.99.1.3) are enzymes that unwind and wind DNA, in order for DNA to control protein synthesis and to reproduce. They cut the DNA and, at the end of the process, connect it again. DOX, an anthracycline antibiotic, interacts with DNA by intercalating between the base pairs of the DNA double helix, thus inhibiting the progression of topo II as it unwinds DNA for transcription and interfering with macromolecular biosynthesis $(33,34)$. Another mechanism of action of DOX appears to be the poisoning of topo II, which results in double-strand DNA breaks; a failure to repair these breaks leads to apoptosis (35). In the present study, topo II protein levels were upregulated in cells treated with EGCG alone or in combination with DOX. Although recent evidence shows that topo II overexpression is correlated to chemoresistance in HCC (36), the roles of topo II in DOX drug resistance are highly controversial $(36,37)$. Given that the accumulation of rho123 was not affected in the presence of elevated topo II protein levels, this enzyme may not play a significant role in mediating the action of catechins on DOX accumulation in the cell. An alternative hypothesis is that catechins may act by inducing the accumulation of topo II as a DOX target (36). The data shown in Table VIII support this hypothesis. Another possibility is that an enhanced level of topo II owing to catechin treatment may facilitate DNA replication and transcription and thereby promote HCC cell proliferation and division; consequently these cells would be more susceptible to DOX therapy, as most anticancer drugs kill rapidly proliferating cells. However, whether catechin-induced accumulation of topo II occurs by increased topo II expression or by enhanced topo II stabilization, and how topo II participates in the reversal of drug resistance by catechins remain unknown.

In conclusion, we identified and characterized the green tea catechins ECG and EGCG as MDR modulators in in vitro and in vivo models for DOX-resistant HCC. We demonstrated that these catechins enhanced chemosensitivity to DOX and increase DOX cytotoxicity in BEL-7404/DOX cells by inhibiting P-gp pump function, thereby elevating the intracellular DOX concentration. ECG and EGCG also modulated the expression of $M D R 1$ and other drug resistance-related genes to contribute to the reversal of MDR in our model systems. Considering the current lack of effective medical treatment options for liver cancer, we advocate the use of green tea catechins as an attractive new modulator of DOX chemotherapy in HCC. The use of an additional drug to modulate DOX anticancer activity would increase a patient's burden of medications and risk for adverse side effects. In contrast, drinking green tea as a modulator in combination with DOX treatment may enhance antitumor activity with no toxic side effects. This promising new therapeutic combination may improve the quality of life in patients receiving cancer chemotherapy and warrants further clinical exploration.

\section{Acknowledgments}

The authors thank Professor Renbin Huang and Professor Ningsheng Liang of Guangxi Medical University School of Pharmaceutical Sciences for their valuable comments on our projects. This work was supported by a grant from the Natural Science Foundation of Guangxi Provincial Department of Science and Technology (no. 0004302).

\section{References}

1. El-Serag HB: Epidemiology of hepatocellular carcinoma in USA. Hepatol Res 37 (Suppl. 2): S88-S94, 2007.

2. El-Serag HB and Rudolph KL: Hepatocellular carcinoma: epidemiology and molecular carcinogenesis. Gastroenterology 132: 2557-2576, 2007.

3. Masuzaki R and Omata M: Treatment of hepatocellular carcinoma. Indian J Gastroenterol 27: 113-122, 2008.

4. Szakacs G, Paterson JK, Ludwig JA, Booth-Genthe C and Gottesman MM: Targeting multidrug resistance in cancer. Nat Rev Drug Discov 5: 219-234, 2006.

5. Takara K, Sakaeda T and Okumura K: An update on overcoming MDR1-mediated multidrug resistance in cancer chemotherapy. Curr Pharm Des 12: 273-286, 2006.

6. Pastore RL and Fratellone P: Potential health benefits of green tea (Camellia sinensis): a narrative review. Explore (NY) 2: 531-539, 2006.

7. Kuo PL and Lin CC: Green tea constituent (-)-epigallocatechin-3gallate inhibits Hep G2 cell proliferation and induces apoptosis through p53-dependent and Fas-mediated pathways. J Biomed Sci 10: 219-227, 2003

8. Jin J, Wang FP, Wei H and Liu G: Reversal of multidrug resistance of cancer through inhibition of P-glycoprotein by 5-bromotetrandrine. Cancer Chemother Pharmacol 55: 179-188, 2005.

9. $\mathrm{Xu} \mathrm{D}, \mathrm{Lu} \mathrm{Q}$ and $\mathrm{Hu} \mathrm{X}$ : Down-regulation of P-glycoprotein expression in MDR breast cancer cell MCF-7/ADR by honokiol. Cancer Lett 243: 274-280, 2006.

10. Elias JM, Gown AM and Nakamura RM: Quality control in immunohistochemistry. Report of a workshop sponsored by the Biological Stain Commission. Am J Clin Pathol 92: 836-843, 1989.

11. Bosch FX, Ribes J, Cleries R and Diaz M: Epidemiology of hepatocellular carcinoma. Clin Liver Dis 9: 191-211, 2005.

12. Okuda K: Hepatocellular carcinoma. J Hepatol 32: 225-237, 2000.

13. Klopman G, Shi LM and Ramu A: Quantitative structureactivity relationship of multidrug resistance reversal agents. Mol Pharmacol 52: 323-334, 1997.

14. Volm M: Multidrug resistance and its reversal. Anticancer Res 18: 2905-2917, 1998

15. Kubota Y, Hosaka M, Fukushima S and Kondo I: Prophylactic oral UFT therapy for superficial bladder cancer. Cancer 71: $1842-1845,1993$. 
16. Ichinose $\mathrm{Y}$, Takanashi $\mathrm{N}$ and Yano $\mathrm{T}$ : A phase II trial of oral tegafur and uracil plus cisplatin in patients with inoperable nonsmall cell lung cancer. Cancer 75: 2677-2680, 1995.

17. Eliason JF, Ramuz H, Yoshikubo T, Ishikawa T, Yamamoto T and Tsuruo T: Novel dithiane analogues of tiapamil with high activity to overcome multidrug resistance in vitro. Biochem Pharmacol 50: 187-196, 1995.

18. Hayashi A, Furusawa S, Takayanagi M, Takasyanagi Y and Sasaki K: Studies on reversing effect of multidrug resistance by dipyridamole. II. Inhibition of epirubicin efflux from resistant cells by dipyridamole and its pharmacological effect. Yakugaku Zasshi 116: 228-237, 1996.

19. Krishna R and Mayer LD: The use of liposomal anticancer agents to determine the roles of drug pharmacodistribution and P-glycoprotein (PGP) blockade in overcoming multidrug resistance (MDR). Anticancer Res 19: 2885-2891, 1999.

20. Lum BL, Gosland MP, Kaubisch S and Sikic BI: Molecular targets in oncology: implications of the multidrug resistance gene. Pharmacotherapy 13: 88-109, 1993.

21. Satoh T, Nishida M, Tsunoda $H$ and Kubo T: Expression of glutathione S-transferase pi (GST-pi) in human malignant ovarian tumors. Eur J Obstet Gynecol Reprod Biol 96: 202-208, 2001.

22. Hill BT, Moran E and Etievant C: Low-dose twice-daily fractionated $\mathrm{X}$-irradiation of ovarian tumor cells in vitro generates drug-resistant cells overexpressing two multidrug resistanceassociated proteins, P-glycoprotein and MRP1. Anticancer Drugs 11: 193-200, 2000

23. Cvitkovic E: Ongoing and unsaid on oxaliplatin: the hope. Br J Cancer 77 (Suppl. 4): 8-11, 1998.

24. Perego P, Giarola M and Righetti SC: Association between cisplatin resistance and mutation of p53 gene and reduced bax expression in ovarian carcinoma cell systems. Cancer Res 56: 556-562, 1996

25. Asselin E, Mills GB and Tsang BK: XIAP regulates Akt activity and caspase-3-dependent cleavage during cisplatin-induced apoptosis in human ovarian epithelial cancer cells. Cancer Res 61: 1862-1868, 2001.

26. Cui W, Yazlovitskaya EM, Mayo MS, Pelling JC and Persons DL: Cisplatin-induced response of c-jun N-terminal kinase 1 and extracellular signal-regulated protein kinases 1 and 2 in a series of cisplatin-resistant ovarian carcinoma cell lines. Mol Carcinog 29: 219-228, 2000
27. Meinhold-Heerlein I, Stenner-Liewen F and Liewen H: Expression and potential role of Fas-associated phosphatase-1 in ovarian cancer. Am J Pathol 158: 1335-1344, 2001.

28. Marin-Hernandez A, Gallardo-Perez JC, Ralph SJ, RodriguezEnriquez S and Moreno-Sanchez R: HIF-1alpha modulates energy metabolism in cancer cells by inducing over-expression of specific glycolytic isoforms. Mini Rev Med Chem 9: 1084-1101, 2009.

29. Semenza GL: HIF-1 inhibitors for cancer therapy: from gene expression to drug discovery. Curr Pharm Des 15: 3839-3843, 2009.

30. Riganti C, Doublier S and Viarisio D: Artemisinin induces doxorubicin resistance in human colon cancer cells via calciumdependent activation of HIF- $1 \alpha$ and P-glycoprotein overexpression. Br J Pharmacol 156: 1054-1066, 2009.

31. Lau CK, Yang ZF and Ho DW: An Akt/hypoxia-inducible factor-1a/platelet-derived growth factor-BB autocrine loop mediates hypoxia-induced chemoresistance in liver cancer cells and tumorigenic hepatic progenitor cells. Clin Cancer Res 15: 3462-3471, 2009

32. Koukourakis MI, Giatromanolaki A and Skarlatos J: Hypoxia inducible factor (HIF-1 $\alpha$ and HIF-2 $\alpha$ ) expression in early esophageal cancer and response to photodynamic therapy and radiotherapy. Cancer Res 61: 1830-1832, 2001.

33. Fornari FA, Randolph JK, Yalowich JC, Ritke MK and Gewirtz DA: Interference by doxorubicin with DNA unwinding in MCF-7 breast tumor cells. Mol Pharmacol 45: 649-656, 1994.

34. Momparler RL, Karon M, Siegel SE and Avila F: Effect of adriamycin on DNA, RNA, and protein synthesis in cell-free systems and intact cells. Cancer Res 36: 2891-2895, 1976.

35. Tewey KM, Rowe TC, Yang L, Halligan BD and Liu LF: Adriamycin-induced DNA damage mediated by mammalian DNA topoisomerase II. Science 226: 466-468, 1984.

36. Wong N, Yeo W and Wong WL: TOP2A overexpression in hepatocellular carcinoma correlates with early age onset, shorter patients survival and chemoresistance. Int J Cancer 124: 644-652, 2009.

37. Kik K, Studzian K, Wasowska-Lukawska M, Oszczapowicz I and Szmigiero L: Cytotoxicity and inhibitory properties against topoisomerase II of doxorubicin and its formamidine derivatives. Acta Biochim Pol 56: 135-142, 2009. 